\title{
Pengembangan Modul Pelatihan Pengelolaan Penilaian Autentik Guru IPA SMP
}

\author{
Vidriana Oktoviana Bano \\ Pendidikan Biologi Fakultas Ilmu-Ilmu Sosial Universitas Kristen Wira Wacana Sumba \\ vidri.2004@gmail.com
}

\begin{abstract}
This research aims to: (1) describe the real condition of authentic assessment of management by science teachers at SMP Negeri 1 in Waingapu; (2) describes the gaps that occur in the management of authentic assessment; and (3) develop training modules in the management of authentic assessments. This Research is Research and Development $(R \& D)$, using the Four $D$ 's model by Thiagarajan, Semmel, and Semmel (1974). Data collection uses interview, questionnaire, observation. Data validation uses source triangulation and technical triangulation. Data analysis techniques through three stages are data reduction, presentation, and conclusion. The results explain (1) teachers of science limited constraints in practicing the attitude and skill assessment of the learners. (2) limited training of Curriculum 2013 especially authentic assessment that has been followed by trainees. (3) the validator team puts the effectiveness of the training module for the management of authentic assessment of science teachers in junior high school in the fair category with a score of 102 out of 150 or $68 \%$. After improving the module and tested it, the training participants' response was $79.75 \%$ in the good category and the educational observers' response was 78,4\% with the good category as well.
\end{abstract}

Keywords: Authentic Assessment, Four D’s Model, R\&D, Science Teacher, Training Module

\section{Article Info}

Received date: 6 Juni $2018 \quad$ Revised date: 30 Juli $2018 \quad$ Accepted date: 8 Desember 2018

\section{PENDAHULUAN}

Penilaian autentik (authentic assessment) merupakan jenis penilaian dalam penerapan kurikulum 2013 yang tengah berlangsung saat ini, yang menurut Kunandar (2013: 35) merupakan aktivitas menilai peserta didik yang memusatkan pada apa yang semestinya dinilai, baik proses maupun hasil dengan beragam instrumen penilaian yang disesuaikan berdasarkan ketentuan kompetensi yang tertera dalam Standar Kompetensi atau Kompetensi Inti dan Kompetensi Dasar. Selain Kunandar, Majid (2014: 57) juga menyimpulkan definisi penilaian autentik dari beberapa sumber sebagai: 'proses pengumpulan berbagai data yang bisa memberikan gambaran perkembangan siswa yang perlu selalu dipantau agar dapat memastikan apakah siswa telah menjalani proses pembelajaran dengan benar'

Berjalannya implementasi Kurikulum 2013 hingga saat ini masih dijumpai kendalakendala yang menghambat efektifitas pelaksanaan kurikulum ini. Salah satu kendala yang dimaksud adalah penilaian autentik, seperti yang diungkapkan oleh Pramita, dkk (2016: 290) yang mengatakan bahwa Kurikulum 2013 akan sulit dilaksanakan di berbagai daerah karena ketidaksiapan guru yang tidak hanya terkait masalah kreativitasnya, melainkan juga masalah 
kompetensi dalam menerapkan kurikulum ini. Berikut beberapa temuan kendala-kendala lainnya di tingkat SD/MI, SMP/MTs dan SMA/MA. Di tingkat SMP/MTs, yakni di MTsN 2 Palangka Raya diungkapkan oleh Abdullah (2016: 60) tentang sistem penilaian autentik dalam pembelajarannya yang dirasa begitu rumit oleh guru Pendidikan Agama Islam. Di tingkat SD/MI, dialami guru-guru di SD Kabupaten Pidie (oleh Ruslan, Tati Fauziah, dan Tuti Alawiyah; 2016: 147) yang menguraikan alasan-alasan dalam masalah penilaian yakni: pertama, banyaknya aspek yang harus dinilai dalam penilaian Kurikulum 2013. Kedua, proses belajar mengajar dirasa menjadi kurang efektif karena bersamaan dengan dilakukannya penilaian. Ketiga, guru merasa terbebani karena setiap nilai yang diperoleh siswa secara keseluruhan harus dijumlahkan lalu dideskripsikan nilai yang didapat tersebut per mata pelajaran. Permasalahan penilaian di tingkat SMA/MA, diungkapkan oleh Syukriya, dkk (2015: 5) melalui teknik wawancara yang menjadikan 20 orang guru Kimia se-Kabupaten Tanggamus sebagai objek penelitiannya menjelaskan: pertama, teknik penilaian terlalu rumit atau membingungkan, demikian pula mekanisme dan prosedur penilaiannya. Kedua, guru belum pernah diutus sekolah untuk mengikuti kegiatan pelatihan Kurikulum 2013. Ketiga, terlalu banyak jumlah siswa yang diampu oleh satu orang guru atau terlalu banyak format yang harus disiapkan.

Permasalahan penilaian autentik dalam penerapan Kurikulum 2013 ternyata juga dialami oleh guru-guru di SMP Negeri tempat penelitian ini, yang menjadi salah satu sekolah rujukan di Kabupaten Sumba Timur. Setelah melakukan wawancara dengan 5 (lima) orang guru IPA terkait penilaian autentik yang telah diterapkan sekolah sejak tahun 2016-2017 diketahui bahwa pemahaman guru terhadap penilaian autentik masih terbatas, guru-guru belum sepenuhnya mengerti bagaimana menerapkan teknik penilaian, demikian juga mekanisme dan prosedur penilaiannya. Hal ini bisa terjadi karena guru-guru tersebut belum pernah dilatih secara khusus atau pelatihanpelatihan yang pernah diikutipun belum menjawab kebutuhan guru tentang penilaian autentik. Dari 5 orang guru IPA tersebut, baru 1 orang guru yang pernah mengikuti pelatihan K13 sebanyak 2 kali yakni pada tahun 2014 dan 2016. Meskipun demikian pelatihan-pelatihan yang pernah diikuti oleh guru-guru IPA tersebut belum sepenuhnya menjawab kebutuhan para guru mengenai penilaian autentik dalam K13 yang diharapkan, ditambah lagi belum adanya tanggapan/ respon/umpan balik bagi guru-guru setelah mengikuti pelatihan K13. Diketahui bahwa di Kabupaten Sumba Timur jumlah sekolah tingkat SMP/MTs yang telah menerapkan K13 sebanyak 46 sekolah dan 31 sekolah belum menggunakan K13 (Dinas Pendidikan Kabupaten Sumba Timur, 2017). Data tersebut menunjukkan bahwa masih banyak sekolah SMP/MTs yang belum siap mengimplementasikan K13 yang berdampak masih begitu besar kebutuhan guru untuk mendapat pelatihan tentang penilaian autentik dalam K13.

Salah satu langkah yang dapat ditempuh guna mengatasi permasalahan yang dihadapi guru-guru di SMP Negeri ini adalah dengan mengembangkan modul pelatihan dalam pengelolaan penilaian autentik. Indriyanti \& Endang Susilowati (2010: 2) mengatakan bahwa modul merupakan suatu cara pengorganisasian materi pelajaran yang memperhatikan fungsi pendidikan yang kegunaannya dapat membuat siswa lebih tertarik dalam belajar, siswa otomatis belajar bertolak dari prerequisites, dan dapat meningkatkan hasil belajar. Hal sama juga diutarakan Daryanto (2013: 9) yang mengatakan bahwa modul merupakan salah satu bentuk bahan ajar yang dikemas secara utuh dan sistematis, di dalamnya memuat seperangkat pengalaman belajar yang terencana 
Pengembangan Modul Pelatihan Pengelolaan Penilaian Autentik Guru IPA SMP | Vidriana O. Bano

dan didesain untuk membantu peserta didik menguasai tujuan belajar yang spesifik. Modul minimal memuat tujuan pembelajaran, materi/substansi belajar, dan evaluasi. Bahan ajar modul ini dipilih karena modul mampu mengatasi keterbatasan waktu, ruang, daya indera, baik siswa maupun guru. Selain itu, modul memungkinkan bagi peserta didik untuk belajar secara mandiri (independent) (Anggraini \& Sukardi, 2016: 25). Mendukung pendapat diatas, Daryanto (2013: 9) juga menyebutkan modul berfungsi sebagai sarana belajar yang bersifat mandiri, sehingga peserta didik dapat belajar secara mandiri sesuai dengan kecepatan masing-masing.

Model pengembangan yang digunakan dalam penelitian ini adalah model 4-D yang dikembangkan pada tahun 1974 oleh Thiagarajan, Semmel, dan Semmel (Trianto, 2012: 93) yang terdiri dari 4 (empat) tahap pengembangan yaitu Pendefinisian (Define), Perancangan (Design), Pengembangan (Develop) dan Pendiseminasian (Disseminate)/ Peneliti memilih model 4-D karena tahapantahapan yang ada jelas dan memaparkan secara ringkas proses pengembangan yang dilakukan. Berikut kelebihan model 4D menurut beberapa peneliti lain. Rochmad (2012: 60) menjelaskan bahwa Desain Model Four-D digunakan untuk alur pengembangan perangkat pembelajaran (instructional development) yang pada dasarnya dimaksudkan untuk pelatihan guru (training teacher) untuk anak-anak berkebutuhan khusus (exceptional children), dan penekanannya pada pengembangan bahan ajar (material development). Trianto (2012: 3) menjelaskan bahwa model 4D merupakan salah satu model desain pembelajaran sistematik. Lebih lanjut Arywiantari, dkk (2015: 3) mengatakan bahwa model ini tersusun secara terprogram dengan urutan-urutan kegiatan yang sistematis dalam upaya pemecahan masalah belajar yang berkaitan dengan suatu sumber belajar yang disesuaikan dengan kebutuhan dan karakteristik pebelajar, dimana salah satu kelebihan 4D yaitu lebih tepat digunakan sebagai dasar untuk mengembangkan perangkat pembelajaran bukan untuk mengembangkan sistem pembelajaran.

Berdasarkan permasalahan di atas, peneliti merasa perlu melakukan penelitian dan pengembangan dengan tujuan sebagai berikut: (a) mendeskripsikan kondisi nyata pengelolaan penilaian autentik; (b) mendeskripsikan kesenjangan yang terjadi dalam pengelolaan penilaian autentik; dan (c) mengembangkan modul pelatihan dalam pengelolaan penilaian autentik khususnya bagi guru mata pelajaran IPA (Ilmu Pengetahuan Alam) di tingkat pendidikan menengah pertama Modul yang dikembangkan diharapkan dapat meningkatkan profesionalis-me pendidik dalam mengaplikasikan penilaian autentik dalam Kurikulum 2013.

\section{METODE PENELITIAN}

Penelitian ini adalah penelitian dan pengembangan. (Research \& Development) Model pengembangan yang digunakan adalah Model 4 D (Four D's Model) yang dikembangkan oleh Thiagarajan, Semmel and Semmel (1974), yang terdiri dari 4 tahap pengembangan yaitu Pendefinisian (Define), Perancangan (Design), Pengembangan (Develop) dan Pendiseminasian (Disseminate). Penelitian ini hanya sampai pada tahap Pengembangan (Develop).

Penelitian dilakukan di SMP Negeri 1 Waingapu yang berlokasi di Jl. I.H. Doko No.6, Prailiu, Kecamatan Kambera, Kabupaten Sumba Timur, Nusa Tenggara Timur. Subyek penelitian adalah Kepala Sekolah, Wakil Kepala Sekolah, guru mata pelajaran IPA di SMP Negeri ini (yang menjadi sasaran khusus sebagai peserta pelatihan, berjumlah 5 orang) dan Kepala Bidang SMP Dinas Pendidikan Kabupaten Sumba Timur. Data penelitian juga dilengkapi dengan hasil penilaian dari tim validasi ahli dan praktisi pendidikan lainnya yang dapat mendukung hasil penelitian ini. 
Kelola: Jurnal Manajemen Pendidikan, Vol. 5, No. 2, Juli-Desember 2018

Waktu pelaksanaan penelitian dimulai sejak bulan September 2017 - Maret 2018.

Pengumpulan data dalam penelitian ini dilakukan dengan teknik interview (wawancara), observasi (pengamatan), studi dokumen, dan kuesioner. Teknik validasi data menggunakan trianggulasi sumber dan trianggulasi teknik. Sedang teknik analisis data menggunakan teknik analisis data kualitatif yang meliputi tiga tahap, yaitu: 1) Reduksi Data (Data Reduction); 2) Penyajian Data (Data Display); 3) Penarikan Kesimpulan (Conclusion Drawing).

\section{HASIL PENELITIAN DAN PEMBAHASAN}

\section{Hasil Penelitian}

Bagian ini menguraikan tentang hasil penelitian dengan mengikuti model pendekatan 4-D.

\section{Tahap 1: Pendefinisian (Define)}

Tahap Pendefinisian adalah tahap untuk menetapkan dan mendefinisikan syarat-syarat pembelajaran. Penjelasan pada tahap ini terbagi dalam 5 fase, yaitu: (1) Analisis awal akhir (front-end analysis); (2) Analisis siswa/pebelajar (learner analysis); (3) Analisis tugas (task analysis); (4) Analisis konsep (concept analysis); (5) Spesifikasi tujuan (specifying instructional objectives), sebagai berikut:

\section{1) Analisis awal akhir (Front-end analysis)}

Analisis awal akhir bertujuan untuk memunculkan dan menetapkan masalah dasar yang dihadapi dalam pembelajaran sehingga diperlukan pengembangan bahan ajar. Dari hasil wawancara terungkap masalah/persoalan mendasar yang dihadapi yaitu peserta pelatihan belum memahami dengan baik dan benar pengelolaan penilaian autentik dalam K13. Hal ini terlihat dari pelaksanaan teknik penilaian sikap (sosial dan spiritual) penilaian autentik yang seharusnya juga dilakukan oleh setiap guru mata pelajaran minimal dilakukan satu kali terhadap seluruh peserta didik dengan menyiapkan instrumen terlebih dahulu (berdasarkan Panduan Penilaian oleh Pendidik dan Satuan Pendidikan dari Kementerian Pendidikan dan Kebudayaan tahun 2017), namun kondisi nyata di lapangan, peserta pelatihan justru mempercayakan penilaian sikap terhadap peserta didik sepenuhnya menjadi tugas Wali kelas atau guru PKN atau guru Agama atau guru BK sementara guru-guru IPA cukup melakukan pengamatan saja atau penilaian tidak langsung. Selain penilaian sikap, ada juga penilaian ketrampilan (praktik, produk, projek, portofolio) yang perlu diterapkan dalam penilaian autentik namun penerapan di lapangan menunjukkan penilaian portofolio dan proyek jarang dipraktekkan pada peserta didik. Guru-guru IPA juga masih merasa binggung dalam membuat instrumen penilaian. Usaha-usaha yang dilakukan guruguru IPA untuk mengevaluasi pengelolaan penilaian autentik yang telah diterapkan di sekolah supaya dapat menjadi lebih baik lagi di semester-semester selanjutnya belum sepenuhnya optimal dilaksanakan. Akibatnya walaupun sekolah secara resmi sudah ditetapkan menjalankan K13 sejak tahun ajaran 2016-2017, namun dalam kenyataannya pelaksanaan pola pengajaran dan penilaian masih menggunakan kurikulum lama, yaitu KTSP 2006.

\section{2) Analisis siswa/pebelajar analysis) \\ Analisis ini dilakukan untuk} mendapatkan gambaran karateristik pebelajar, antara lain: (a) tingkat kemampuan atau perkembangan intelektualnya, (b) ketrampilanketrampilan individu atau sosial yang sudah dimiliki dan dapat dikembangkan untuk mencapai tujuan pembelajaran yang ditetapkan.

Diketahui bahwa kelima peserta pelatihan mempunyai latar belakang pendidikan Sarjana Strata-1 dari beberapa kampus negeri dan swata di Indonesia, mempunyai pengalaman dalam melakukan pendampingan terhadap peserta didik 
Pengembangan Modul Pelatihan Pengelolaan Penilaian Autentik Guru IPA SMP | Vidriana O. Bano

mengikuti perlombaan baik di tingkat Kecamatan maupun tingkat Kabupaten. Guru AM (ठ) menjadi salah seorang guru senior di sekolah tersebut, dengan lama pengabdian 24 tahun, disusul oleh guru EB ( $P$ ) dengan lama pengabdian 14 tahun, guru MA (q) 12 tahun, guru VD (ㅇ) selama 7 tahun dan guru $\mathrm{AH}($ ぶ) selama 4 bulan terhitung sejak Okt 2017.

3) Analisis tugas (Task analysis)

Analisis tugas bertujuan untuk mengidentifikasi ketrampilan-ketrampilan utama yang akan dikaji oleh peneliti dan menganalisisnya ke dalam himpunan ketrampilan tambahan yang mungkin diperlukan. Analisis ini memastikan ulasan yang menyeluruh tentang tugas dalam materi pembelajaran.

Tugas-tugas yang dilakukan peserta pelatihan pada saat pelatihan dengan menggunakan produk modul yang dikembangkan, antara lain: (a) menentukan Kriteria Belajar Minimal (KBM) mata pelajaran, (b) membuat rubrik penilaian untuk penilaian sikap peserta didik, (c) membuat deskripsi penilaian sikap peserta didik dalam rapor.

\section{4) Analisis konsep (Concept analysis)}

Analisis konsep merupakan identifikasi komponen materi yang akan diajarkan kepada peserta pelatihan, yang dibuat dalam peta konsep sehingga memudahkan peserta pelatihan dalam pembelajaran. Tahap ini merupakan pengidentifikasian konsep utama yang akan diajarkan dan menyusunnya secara sistematis dengan merinci konsep materi dalam bentuk peta konsep, seperti gambar dibawah ini:

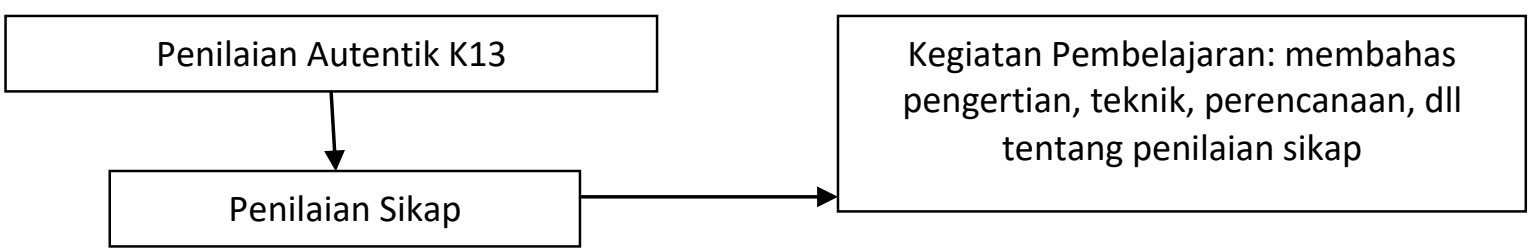

Gambar 1. Peta konsep penilaian autentik

\section{5) Spesifikasi Tujuan (Specifying instructional objectives)}

Di fase ini, peneliti akan mengubah hasil analisis tugas (ketrampilan utama) dan hasil hasil analisis konsep (konsep-konsep pokok) ke dalam rumusan tujuan-tujuan pelatihan dalam bentuk perilaku-perilaku teramati tertentu. Adapun hasil perumusan tujuan pelatihan yang dilakukan adalah (1) peserta pelatihan dapat memahami konsep penilaian autentik dalam kurikulum 2013; (2) peserta pelatihan dapat memahami dan melakukan penilaian sikap; (3) peserta pelatihan dapat memahami dan melakukan penilaian pengetahuan; (4) peserta pelatihan dapat memahami dan melakukan penilaian ketrampilan.

\section{Tahap 2: Perancangan (Design)}

Tahap perancangan ini bertujuan untuk merancang perangkat pembelajaran. Ada 4 langkah yang harus dilakukan pada tahap ini, yaitu sebagai berikut:

\section{1) Penyusunan Tes (Criterion-test construction)}

Penyusunan tes pada penelitian ini difokuskan pada tes akhir setelah pelatihan menggunakan Modul Pelatihan Pengelolaan Penilaian Autentik Guru IPA SMP. Tes yang disusun berupa tes akhir (post test) sebagai evaluasi untuk mengetahui hasil belajar atau uji kompetensi peserta pelatihan setelah pembelajaran menggunakan Modul Pelatihan Pengelolaan Penilaian Autentik Guru IPA SMP. Adapun jenis evalusinya berupa tes formatif berupa tes pilihan ganda dalam setiap kegiatan pembelajaran. Adapula umpan balik dan tindak lanjut yang perlu dilakukan peserta pelatihan diakhir setiap materi. 
Kelola: Jurnal Manajemen Pendidikan, Vol. 5, No. 2, Juli-Desember 2018

\section{2) Pemilihan Media (Media selection)}

Media pembelajaran atau sarana yang diperlukan yang digunakan pada pelatihan ini adalah berupa perlengkapan alat kantor (ATK) yang terdiri dari: Pena/Pulpen, Pensil dan note book. Peserta pelatihan juga dapat menggunakan laptop masing-masing jika ingin membaca materi pelatihan dalam bentuk soft file.

\section{3) Pemilihan Format (Format selection)}

Pemilihan format pada tahap perencanaan ini merupakan pemilihan metode pembelajaran dalam pelatihan yang memungkinkan peserta pelatihan lebih mudah menangkap materi ajar yang disampaikan oleh instruktur. Metode pembelajaran yang digunakan dalam pelatihan penelitian ini adalah metode pembelajaran langsung (direct instruction), dengan melakukan diskusi-diskusi terkait materi ajar dan pengalaman-pengalaman rill (nyata) peserta pelatihan selama mengabdi.

Adapun Modul Pelatihan Pengelolaan Penilaian Autentik Guru IPA SMP dikembangkan berdasarkan buku Panduan
Penilaian oleh Pendidik dan Satuan Pendidikan untuk SMP, oleh Kementerian Pendidikan dan Kebudayaan, Direktorak Jenderal Pendidikan Dasar Dan Menengah, Direktorat Pembinaan Sekolah Menengah Pertama Tahun 2017. Dalam modul tersebut, peneliti mengembangkannya dengan menambahkan contoh-contoh penilaian dalam mata pelajaran IPA sehingga modul tersebut dapat memfasilitasi guru IPA secara khusus dalam merencanakan, melaksanakan, dan melaporkan serta memanfaatkan hasil penilaian baik aspek sikap, aspek pengetahuan, dan aspek keterampilan.

\section{4) Rancangan Awal (Initial design)}

Pada tahap ini, instrumen dan buku modul pelatihan dikembangkan secara sederhana sebagai rancangan awal. Rancangan awal berfungsi sebagai desain sebelum instrumen dan buku modul tersebut diujicobakan. Berikut ini adalah desain rancangan awal buku modul Pelatihan Pengelolaan Penilaian Autentik Guru IPA SMP.

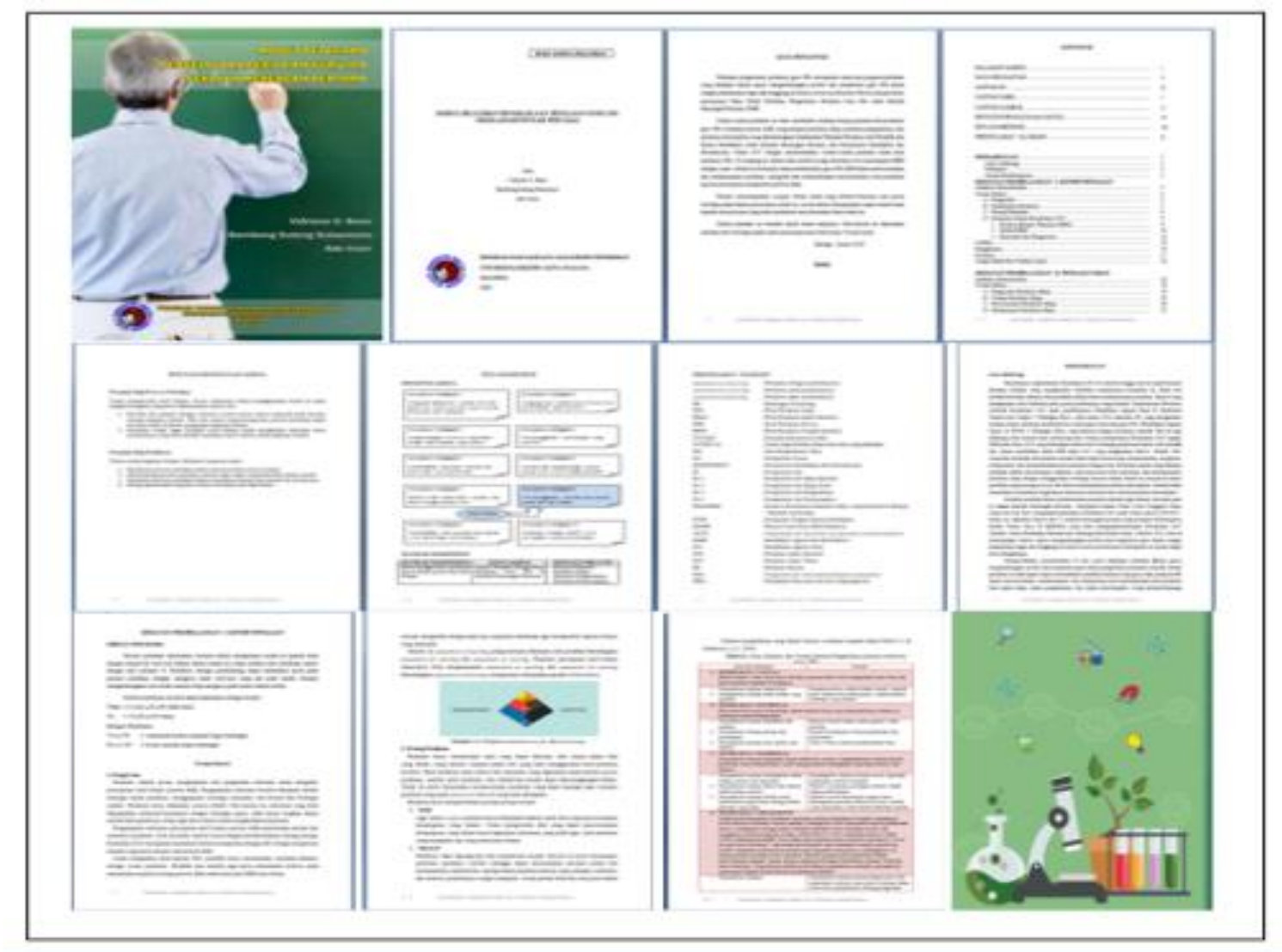

Gambar 2. Rancangan awal modul 
Pengembangan Modul Pelatihan Pengelolaan Penilaian Autentik Guru IPA SMP | Vidriana O. Bano

\section{Tahap 3: Pengembangan (Develop)}

Tahap pengembangan yang merupakan tahap terakhir dalam penelitian ini bertujuan untuk menghasilkan produk pengembangan perangkat pembelajaran dalam hal ini modul dan instrumen yang sudah direvisi berdasarkan masukan dari para ahli.
1) Validasi ahli/praktisi (Expert appraisal)

Tahap validasi buku modul difokuskan untuk mendapatkan sebuah modul pelatihan yang layak dan efektif untuk digunakan dengan memperhatikan masukan dari berbagai pihak. Adapun hasil validasi dari para ahli adalah sebagai berikut:

Tabel 1. Penilaian Ahli dan Praktisi terhadap Modul

\begin{tabular}{cccccccccccc}
\hline \multirow{2}{*}{ Validator } & \multicolumn{10}{c}{ Pertanyaan } & \multirow{2}{*}{ Jumlah } \\
\cline { 2 - 10 } & 1 & 2 & 3 & 4 & 5 & 6 & 7 & 8 & 9 & 10 & \\
\hline 1 & 3 & 3 & 2 & 3 & 2 & 2 & 3 & 3 & 3 & 3 & 27 \\
\hline 2 & 2 & 3 & 4 & 4 & 4 & 4 & 4 & 3 & 4 & 4 & 36 \\
\hline 3 & 4 & 4 & 4 & 4 & 4 & 4 & 4 & 4 & 3 & 4 & 39 \\
\hline \multicolumn{1}{l}{ Jumlah Skor Hasil Pengumpulan Data } \\
\multicolumn{10}{l}{ Sumber: Data penelitian }
\end{tabular}

Dari tabel diatas, dapat diinterpretasi nilai 102 termasuk dalam kategori interval cukup jelas/sesuai/operasional atau bernilai
68\% yang terletak pada daerah cukup. Secara kontinum dapat dibuat kategori sebagai berikut.

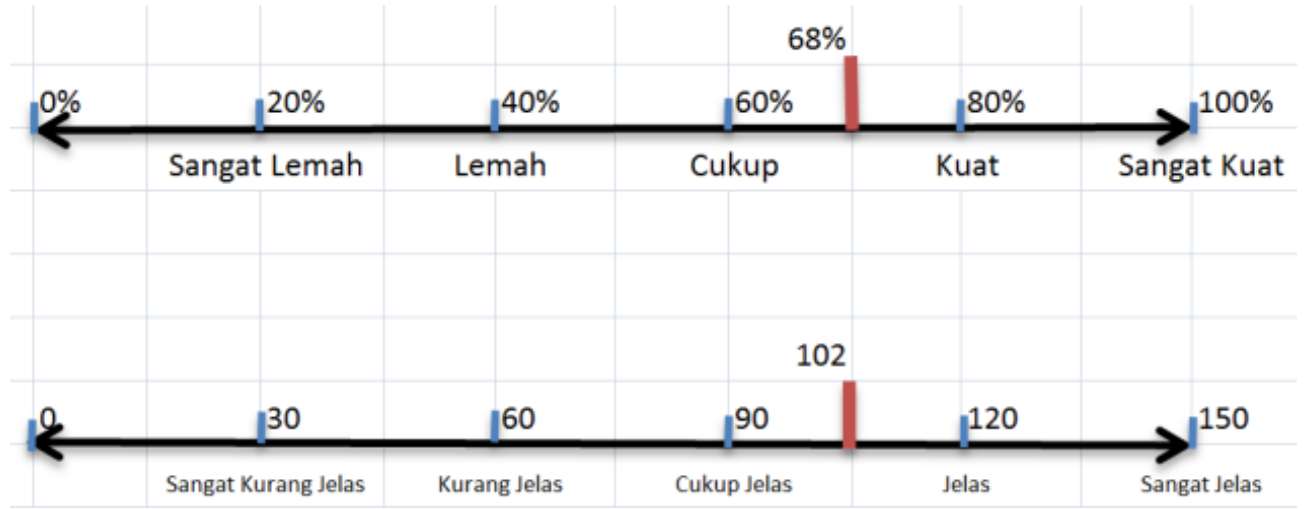

Gambar 3. Hasil penilaian skala sikap validasi ahli/praktisi

Berdasarkan data kuantitatif dan kualitatif yang diperoleh dari validasi ahli/praktisi di atas menjadi input positive bagi peneliti dalam mengkoreksi, membenahi dan mengembangkan modul pelatihan pengelolaan penilaian autentik guru IPA di SMP Negeri ini menjadi lebih baik lagi.

\section{2) Uji coba pengembangan (Developmental testing)}

Kegiatan uji coba merupakan kegiatan penerapan sesuangguhnya terhadap guru-guru IPA di SMP Negeri ini. Pada tahap uji coba ini, ada beberapa kegiatan yang diamati, seperti: aktivitas guru IPA selama pelatihan, hasil pelatihan guru IPA, respon guru IPA terhadap modul pelatihan serta respon praktisi pendidikan terhadap modul pelatihan yang dikembangkan.

1) Aktivitas peserta pelatihan

Aktivitas bapak/ibu guru IPA yang dimaksud dalam penelitian ini adalah antara lain:

- Membaca dan memperhatikan dengan seksama uraian-uraian materi yang ada pada masing-masing kegiatan belajar.

- Berdiskusi tentang topik pembelajaran yang dirasa belum paham, berdiskusi tentang umpan balik dan tindak lanjut yang perlu dilakukan dari setiap setiap kegiatan.

Peserta pelatihan terlihat sangat antusias dalam melakukan aktivitas pelatihan menggunakan modul tersebut. 
2) Hasil pelatihan guru IPA

Hasil pelatihan guru merupakan kemampuan yang diperoleh masing-masing guru setelah proses pelatihan berlangsung, yang dapat memberikan perubahan tingkah laku baik pengetahuan, pemahaman, sikap dan ketrampilan guru sehingga menjadi lebih baik. Hasil pelatihan guru IPA pada uji coba terbatas pada penelitian ini terbagi menjadi tiga bagian, yaitu:

- Kognitif

Hasil pelatihan kognitif peserta pelatihan pada saat uji coba terbatas dengan menggunakan modul pelatihan pengelolaan penilaian autentik dapat dilihat pada Tabel 2. Pelatihan kognitif tersebut dilakukan menggunakan tes pilihan ganda dengan pemberian skor (berskala 10-100) terhadap jawaban yang benar mengikuti aturan:

$$
\mathrm{Sk}=B-\frac{S}{0-1}
$$

Tabel 2. Penilaian hasil pelatihan kognitif peserta pelatihan

\begin{tabular}{cccl}
\hline No & Nama Guru IPA & Nilai & \multicolumn{1}{c}{ Keterangan } \\
\hline 1. & AM & 95 & Di atas minimal tanpa bimbingan \\
\hline 2. & EB & 85 & Memenuhi kriteria minimal tanpa bimbingan \\
\hline 3. & MA & 90 & Di atas minimal tanpa bimbingan \\
\hline 4. & VD & 77.5 & Memenuhi kriteria minimal tanpa bimbingan \\
\hline 5. & AH & 87.5 & Memenuhi kriteria minimal tanpa bimbingan \\
\hline
\end{tabular}

Sumber: Data penelitian

\section{- Afektif}

Hasil penilaian afektif peserta pelatihan dapat terlihat jelas dengan adanya sikap yang antusias dan bertanggung jawab dalam menyelesaikan tugas/latihan serta evaluasi dari setiap kegiatan pembelajaran yang diberikan.

\section{- Psikomotorik}

Hasil pelatihan psikomotorik peserta pelatihan pada saat uji coba terbatas dengan menggunakan modul dapat dilihat pada Tabel 3.

Tabel 3. Penilaian hasil pelatihan psikomotorik peserta pelatihan

\begin{tabular}{cccl}
\hline No & Nama Guru IPA & Nilai & \multicolumn{1}{c}{ Keterangan } \\
\hline 1. & AM & 80 & Memenuhi kriteria minimal tanpa bimbingan \\
\hline 2. & EB & 85 & Memenuhi kriteria minimal tanpa bimbingan \\
\hline 3. & MA & 77.5 & Memenuhi kriteria minimal tanpa bimbingan \\
\hline 4. & VD & 90 & Di atas minimal tanpa bimbingan \\
\hline 5. & AH & 75 & Memenuhi kriteria minimal tanpa bimbingan \\
\hline Sumber: Data penelitian & &
\end{tabular}

3) Respon peserta pelatihan terhadap modul

Peneliti juga membagikan kuesioner untuk mengukur respon peserta pelatihan terhadap modul pelatihan. Respon peserta dapat di lihat pada tabel 4 berikut.

Tabel 4. Respon peserta pelatihan terhadap modul pelatihan

\begin{tabular}{cccccc}
\hline \multirow{2}{*}{ Pertanyaan } & \multicolumn{6}{c}{ Nama Guru IPA } \\
\cline { 2 - 6 } & AM & EB & MA & VD & AH \\
\hline 1 & 3 & 3 & 3 & 4 & 3 \\
\hline 2 & 3 & 3 & 3 & 3 & 3 \\
\hline 3 & 3 & 3 & 3 & 4 & 3 \\
\hline 4 & 3 & 3 & 3 & 3 & 3 \\
\hline 5 & 3 & 3 & 3 & 3 & 3 \\
\hline 6 & 3 & 3 & 3 & 4 & 4 \\
\hline 7 & 3 & 3 & 3 & 4 & 3 \\
\hline 8 & 3 & 3 & 3 & 3 & 3 \\
\hline
\end{tabular}


Pengembangan Modul Pelatihan Pengelolaan Penilaian Autentik Guru IPA SMP | Vidriana O. Bano

\begin{tabular}{cccccc}
\hline 9 & 3 & 3 & 3 & 3 & 3 \\
\hline 10 & 3 & 3 & 3 & 4 & 4 \\
\hline 11 & 3 & 3 & 3 & 4 & 4 \\
\hline 12 & 3 & 2 & 3 & 4 & 4 \\
\hline 13 & 3 & 3 & 3 & 4 & 4 \\
\hline 14 & 3 & 3 & 3 & 3 & 4 \\
\hline 15 & 3 & 4 & 3 & 4 & 4 \\
\hline 16 & 3 & 3 & 3 & 3 & 4 \\
\hline 17 & 3 & 3 & 3 & 4 & 4 \\
\hline 18 & 3 & 3 & 3 & 3 & 3 \\
\hline 19 & 3 & 3 & 3 & 3 & 3 \\
\hline 20 & 3 & 3 & 3 & 3 & 3 \\
\hline Jumlah & $\mathbf{6 0}$ & $\mathbf{6 0}$ & $\mathbf{6 0}$ & $\mathbf{7 0}$ & $\mathbf{6 9}$ \\
\hline Jumlah Skor & & & $\mathbf{3 1 9}$ & & \\
\hline Sula pron & & & &
\end{tabular}

Sumber: Data penelitian

Tabel diatas, menunjukkan bahwa total nilai dari peserta adalah 319 yang termasuk dalam kategori interval baik, atau mempunyai nilai $79,75 \%$ yang terletak pada daerah kuat. Secara kontinum dapat dibuat kategori sebagai berikut.

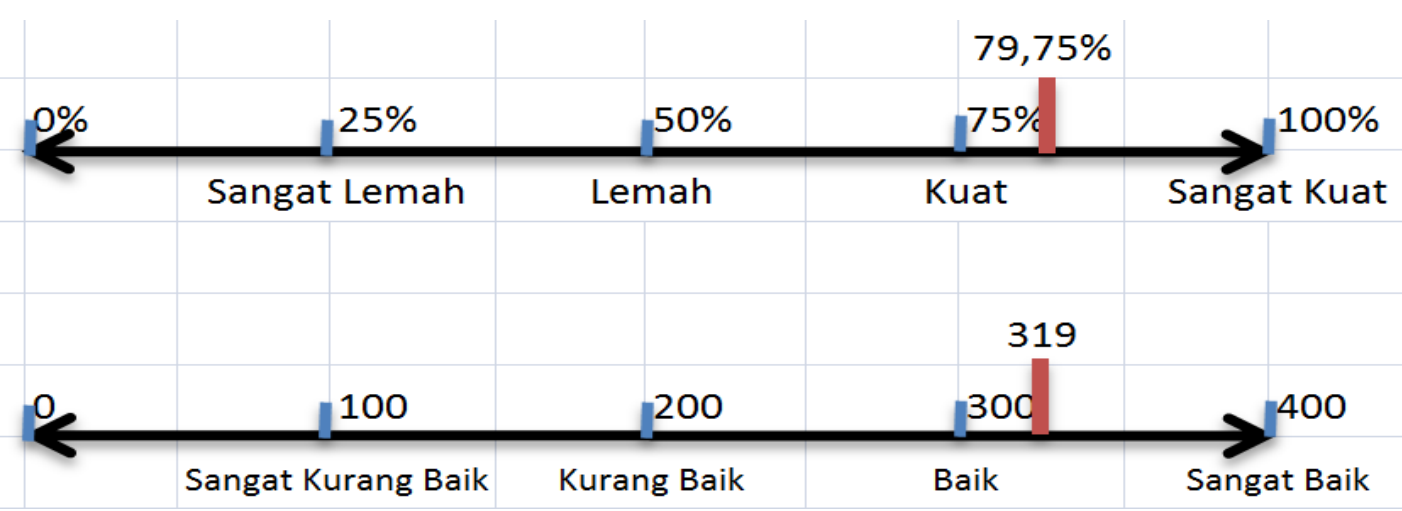

Gambar 5. Skala sikap peserta pelatihan terhadap modul

4) Respon praktisi pendidikan terhadap modul pelatihan

Selain respon dari peserta pelatihan terhadap modul pelatihan pengelolaan penilaian yang dikembangkan, peneliti juga melibatkan beberapa orang praktisi dalam dunia pendidikan. Nama, jabatan dan respon beberapa orang praktisi tersebut dapat di lihat pada tabel 5. sebagai berikut.

Tabel 5. Respon Praktisi Pendidikan terhadap Modul Pelatihan

\begin{tabular}{ccccc}
\hline Pertanyaan & $\begin{array}{c}\text { Kepala Sekolah } \\
\text { SMPN 1 } \\
\text { Waingapu }\end{array}$ & $\begin{array}{c}\text { Kepala Sekolah } \\
\text { SMP Kristen } \\
\text { Waingapu }\end{array}$ & $\begin{array}{c}\text { Kepala Sekolah SMP } \\
\text { Muhammadiyah } \\
\text { (Ketua MGMP IPA } \\
\text { Waingapu) }\end{array}$ & $\begin{array}{c}\text { Instruktur } \\
\text { Nasional K13 }\end{array}$ \\
\hline 1 & 3 & 3 & 3 & 3 \\
\hline 2 & 3 & 3 & 4 & 3 \\
\hline 3 & 3 & 3 & 3 & 3 \\
\hline 4 & 4 & 3 & 3 & 3 \\
\hline 5 & 4 & 3 & 3 & 3 \\
\hline 6 & 4 & 3 & 3 & 3 \\
\hline 7 & 4 & 3 & 3 & 3 \\
\hline 8 & 4 & 3 & & \\
\hline 9 & 4 & 3 & & 3 \\
\hline
\end{tabular}


Kelola: Jurnal Manajemen Pendidikan, Vol. 5, No. 2, Juli-Desember 2018

\begin{tabular}{ccccc}
\hline 10 & 4 & 3 & 3 & 3 \\
\hline 11 & 3 & 3 & 3 & 2 \\
\hline 12 & 3 & 3 & 3 & 2 \\
\hline 13 & 3 & 3 & 4 & 2 \\
\hline 14 & 3 & 3 & 4 & 3 \\
\hline 15 & 4 & 3 & 4 & 3 \\
\hline 16 & 3 & 3 & 3 & 4 \\
\hline 17 & 3 & 3 & 3 & 4 \\
\hline 18 & 4 & 3 & 4 & 59 \\
\hline 19 & 3 & 3 & 66 & \\
\hline 20 & 4 & 3 & & \\
\hline Jumlah & 66 & 60 & &
\end{tabular}

Sumber: Data penelitian

Apabila diinterpretasi nilai 251 termasuk dalam kategori interval baik atau bernilai 78,4\% yang terletak pada daerah kuat.

Secara kontinum dapat dibuat kategori sebagai berikut.

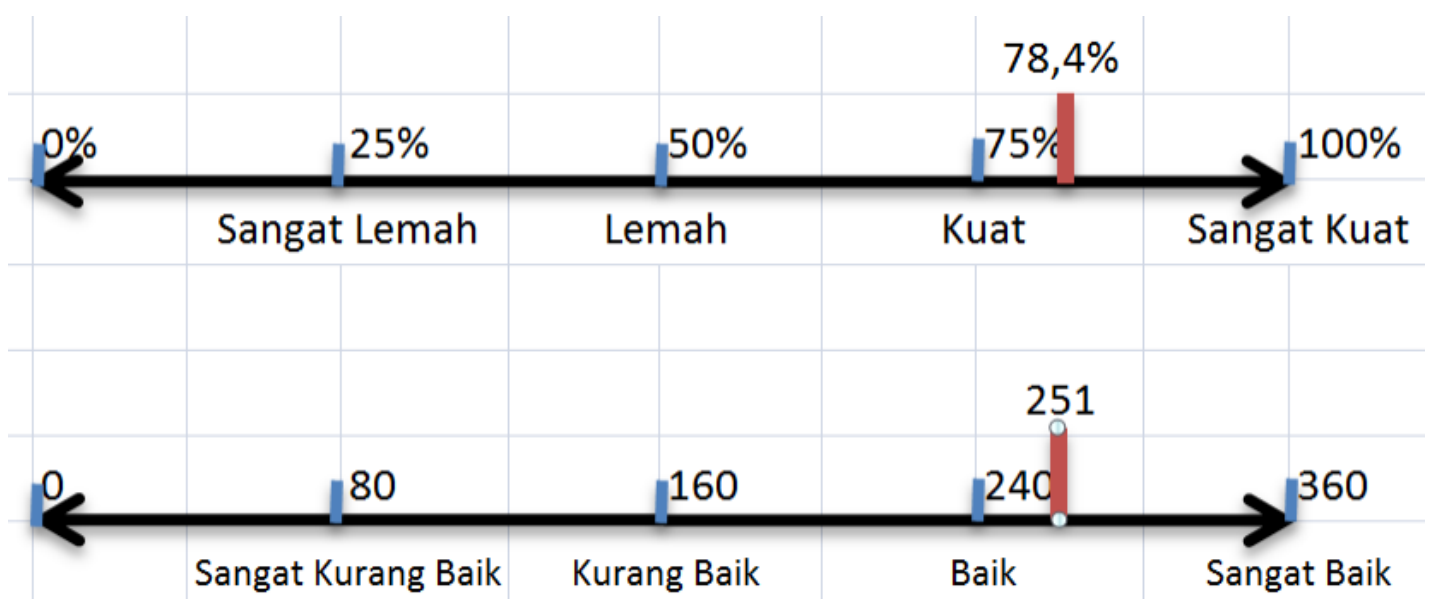

Gambar 6. Skala sikap praktisi pendidikan terhadap keefektifan modul

\section{Pembahasan}

Dari tahap pendefinisian dalam pengembangan ini, telah ditemukan a) permasalahan yang dihadapi para guru dalam melaksanakan penilaian autentik, yang memicu adanya kebutuhan akan modul pelatihan $b$ ) karakteristik para calon pengguna modul, c) tugas-tugas yang harus dilakukan oleh pengguna modul, d) konsep-konsep pokok yang semestinya ada dalam modul dan e) rumusan tujuan pelatihan. Hasil tersebut sejalan dengan teori pengembangan dari Thiagarajan, Semmel, dan Semmel (1974), yang menyatakan bahwa hakikat tahap define (tahap pendefinisian) adalah proses untuk menentukan dan mendefinisikan kebutuhan-kebutuhan di dalam proses pembelajaran/ pelatihan serta 148 mengumpulkan berbagai informasi yang berkaitan dengan produk yang akan dikembangkan. Dengan demikian tahapan ini hakikatnya sejalan dengan tahap analyze dalam pengembangan model ADDIE (Branch, 2009) atau tahap Potensi dan Masalah dalam langkahlangkah pengembangan sebagai disebut oleh Sugiyono (2011).

Temuan tentang kebutuhan modul pelatihan pada tahap pendefinisian di atas sejalan dengan hasil penelitian Giarti (2017) yang di tahap studi pendahuluannya menemukan adanya kebutuhan akan modul pelatihan karya tulis ilmiah hasil PTK akibat rendahnya kompetensi guru dalam menulis karya tulis ilmiah, karena kemandirian guru yang belum mencukupi untuk mengakses 
sumber-sumber karya ilmiah, belum tepatnya metode pelatihan yang diadakan selama ini dan belum memadainya kemampuan pelatih dalam merancang modul pelatihan yang memungkinkan guru untuk belajar secara mandiri.

Pada tahap perancangan, peneliti telah menghasilkan rancangan awal Modul Pelatihan Pengelolaan Penilaian Autentik Guru IPA SMP setelah didahului dengan penyusunan alat evaluasi (tes), pemilihan mediaa dan pemilihan format pembelajaran/ pelatihan. Hasil tersebut sejalan dengan teori pengembangan dari Thiagarajan, Semmel, dan Semmel (1974), yang menyatakan bahwa hakikat tahap design (tahap perancangan) adalah proses merancang produk pembelajaran guna memenuhi kebutuhan yang sudah diidentifikasi pada tahap pendefinisian. Dengan demikian tahapan ini hakikatnya sejalan dengan tahap design dalam pengembangan model ADDIE (Branch, 2009) atau tahap perancangan/disain dalam langkahlangkah pengembangan sebagai disebut oleh Sugiyono (2011). Keberhasilan menyusun produk berupa draft modul pada akhir tahap penrancangan di atas sejalan dengan penelitian Giarti (2017) yang pada langkah perancangan modul (blue print modul) berhasil mengembangkan kerangka modul yang terdiri dari 9 topik seperti tersebut di atas, berhasil merancang portal berbasis $\underline{C M S}$ Moodle, dan kisi-kisi evaluasi.

$\begin{array}{cclc}\text { Pada tahap } & \text { develop } & \text { (tahap } \\ \text { pengembangan) } & \text { telah } & \text { dihasilkan } & \text { modul }\end{array}$
pelatihan dan instrument-instrumen yang diperlukan guna validasi ahli maupun uji coba produk. Penilaian validator menempatkan keefektifan modul pelatihan pada kategori cukup, peserta menilai modul dalam kategori baik dan praktisi pendidikan menilai modul pada kategori baik. Hasil tersebut sejalan dengan teori pengembangan dari Thiagarajan, Semmel, dan Semmel (1974), yang menyatakan bahwa hakikat tahap develop (tahap pengembangan) adalah tahap menghasilkan produk pengembangan yang dilakukan melalui dua langkah, yakni: (1) penilaian ahli (expert appraisal) yang diikuti dengan revisi, dan (2) uji coba pengembangan (developmental testing). Dengan demikian tahapan ini hakikatnya sejalan dengan tahap develop dalam pengembangan model ADDIE (Branch, 2009) atau tahap validasi desain, revisi desain, ujicoba terbatas dan revisi produk dalam langkahlangkah pengembangan sebagai disebut oleh Sugiyono (2011).

\section{SIMPULAN DAN SARAN \\ Simpulan}

Berdasarkan penelitian menggunakan Model 4D dalam pengembangan modul pelatihan pengelolaan penilaian guru IPA Sekolah Menengah Pertama dapat disimpulkan bahwa:

Kodisi nyata pengelolaan penilaian autentik guru IPA. Guru-guru IPA belum memahami dengan baik dan benar pengelolaan penilaian autentik dalam K13. Guru-guru IPA belum melaksanakan penilaian sikap (sosial dan spiritual); Guru-guru IPA juga masih binggung dalam membuat instrumen penilaian ketrampilan (praktik, produk, projek, portofolio). Usaha-usaha yang dilakukan guruguru IPA untuk mengevaluasi pengelolaan penilaian autentik yang telah diterapkan di sekolah supaya dapat menjadi lebih baik lagi di semester-semester selanjutnya belum sepenuhnya optimal dilaksanakan. Akibatnya walaupun sekolah secara resmi sudah ditetapkan menjalankan K13 sejak tahun ajaran 2016-2017, namun dalam kenyataannya pelaksanaan pola pengajaran dan penilaian masih menggunakan kurikulum lama, yaitu KTSP 2006.

\section{Kesenjangan dalam pengelolaan} penilaian autentik guru IPA. Salah satu persoalan mendasar yang dihadapi guru-guru IPA SMP adalah minimnya kesempatan mengikuti pelatihan K13 tentang penilaian autentik. Pelatihan-pelatihan yang pernah 
Kelola: Jurnal Manajemen Pendidikan, Vol. 5, No. 2, Juli-Desember 2018

diikuti oleh guru-guru IPA belum sepenuhnya menjawab kebutuhan para guru mengenai penilaian autentik dalam K13.

Modul pelatihan dalam pengelolaan penilaian autentik guru IPA. Modul Pelatihan Pengelolaan Penilaian Guru IPA SMP dikembangkan berdasarkan buku Panduan Penilaian oleh Pendidik dan Satuan Pendidikan untuk SMP, oleh Kementerian Pendidikan dan Kebudayaan, Direktorat Jenderal Pendidikan Dasar Dan Menengah, Direktorat Pembinaan Sekolah Menengah Pertama Tahun 2017 dengan menambahkan contoh-contoh penilaian dalam mata pelajaran IPA sehingga dapat memfasilitasi guru IPA dalam merencanakan, melaksanakan, dan melaporkan serta memanfaatkan hasil penilaian baik aspek sikap, aspek pengetahuan, dan aspek keterampilan.

Hasil dari penilaian validator menempatkan keefektifan terhadap modul pelatihan pengelolaan penilaian autentik guru IPA pada kategori cukup. Respon peserta pelatihan terhadap modul pada kategori baik dan respon praktisi pendidikan terhadap modul menunjukkan respon positif dengan kategori baik.

\section{Saran}

a. Bagi guru atau pendidik IPA, setelah membaca buku modul ini diharapkan dapat menerapkan dan mengaplikasikan pengelolaan penilaian autentik dengan baik dan benar terhadap peserta didik.

b. Bagi Kepala Sekolah, diharapkan untuk terus mengoptimalkan profesionalisme guru dalam pengelolaan penilaian autentik, juga bagi pendidik awam di sekolahnya.

c. Bagi Dinas Pendidikan, diharapkan untuk terus melakukan upaya pengembangan profesionalitas guru atau pendidik melalui buku-buku modul sehingga membawa dampak terhadap kemandirian guru untuk membaca dan meng-up grade diri.

\section{DAFTAR PUSTAKA}

Abdullah. Implementasi Penilaian Autentik Kurikulum 2013 Pada Pembelajaran Pendidikan Agama Islam Di Madrasah Tsanawiyah Negeri 2 Palangka Raya. FITRAH Jurnal Kajian Ilmu-ilmu Keislaman 2 (2), 59 - 82.

Anggraini \& Sukardi. Pengembangan Modul Pembelajaran Kewirausahaan Model Student Company Di SMK Negeri 1 Godean. Jurnal Pendidikan Vokasi. 6 (1), $24-30$.

Arywiantari, D., A. A. Gede Agung., I Dewa Kade Sastra. 2015. Pengembangan Multimedia Interaktif Model 4D Pada Pembelajaran IPA Di SMP Negeri 3 Singaraja. e-Journal Edutech Universitas Pendidikan Ganesha Jurusan Teknologi Pendidikan 3 (1), 1 12.

Branch, Robert Maribe. 2009. Instructional Design: The ADDIE Approach. New York : Springer Science \& Business Media, LLC. 2009

Daryanto. 2013. Menyusun Modul (Bahan Ajar untuk Persiapan Guru dalam Mengajar). Yogyakarta: Penerbit Gava Media.

Giarti, Sri. 2017. Pengembangan Modul Pelatihan Penulisan Karya Ilmiah Berbasis Andragogi Berbantuan CMS Moodle. Kelola: Jurnal Manajemen Pendidikan, https://doi.org/https://doi.org/10.24246/ j.jk.2016.v3.i2.p\%25p

Indriyanti, N.Y \& Endang Susilowati. 2010. Pengembangan Model. Tim Pengabdian Kepada Masyarakat, Lembaga Penelitian dan Pengabdian Masyarakat, Universitas Sebelas Maret. Diberikan dalam Pelatihan Pembuatan e-module bagi Guru-guru IPA Biologi SMP seKota Surakarta menuju Open Education 
Pengembangan Modul Pelatihan Pengelolaan Penilaian Autentik Guru IPA SMP | Vidriana O. Bano

Resources, Pada tanggal 7 Agustus 2010. 1 - 10 .

Kunandar. 2013. Penilaian Autentik (Penilaian Hasil Belajar Peserta Didik Berdasarkan Kurikulum 2013). Jakarta: PT RajaGrafindo Persada.

Majid, Abdul. 2014. Penilaian Autentik. Proses Dan Hasil Belajar. Bandung: PT Remaja Rosdakarya.

Pramita, M., Sri Mulyati., Hery Susanto. 2016. Implementasi Desain Pembelajaran Pada Kurikulum 2013 Dengan Pendekatan Kontekstual. Jurnal Pendidikan: Teori, Penelitian, dan Pengembangan, 1 (3), 289 - 296.

Rochmad. 2012. Desain Model Pengembangan Perangkat Pembelajaran Matematika. Jurnal Kreano. Diterbitkan oleh Jurusan Matematika FMIPA UNNES. 3 (1), 59 - 72 .

Ruslan, Tati Fauziah, Tuti Alawiyah. 2016. Kendala Guru Dalam Menerapkan Penilaian Autentik di SD Kabupaten
Pidie. Jurnal Ilmiah Mahasiswa Pendidikan Guru Sekolah Dasar FKIP Unsyiah, 1 (1), 147-157.

Sugiyono, 2011. Metode Penelitian Kuantitatif, Kualitatif dan R\&D. Jakarta : Alfhabeta

Syukriya, H., Herpratiwi., Dwi Yulianti. 2015. Evaluasi Implementasi Penilaian Kurikulum 2013 Mata Pelajaran Kimia Kelas XI Di Kabupaten Tanggamus. (download.portalgaruda.org/article.ph p? article $=372903 \&$ val $=7224 \&$ title...) di unduh pada tanggal 02/09/2017 pkl 22:02 wib.

Thiagarajan.S., Semmel, D. S., \& Semmel, M. I., 1974. Instructional Development for Training Teachers of Exceptional Children. Blomington: Indiana University.

Trianto. 2012. Model Pembelajaran Terpatu: Konsep, Strategi, dan Implementasinya dalam Kurikulum Tingkat Satuan Pendidikan (KTSP). Jakarta: Bumi Aksara. 